\title{
Front Matter: Volume 11504
}

, "Front Matter: Volume 11504," Proc. SPIE 11504, Imaging Spectrometry XXIV: Applications, Sensors, and Processing, 1150401 (30 September 2020); doi: $10.1117 / 12.2581605$

SPIE. Event: SPIE Optical Engineering + Applications, 2020, Online Only 


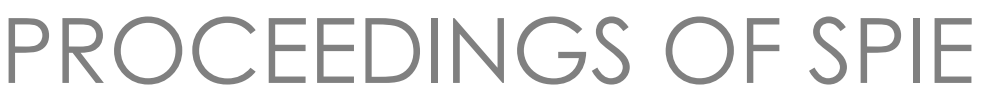

\title{
Imaging Spectrometry XXIV: Applications, Sensors, and Processing
}

\author{
Emmett J. lentilucci \\ Pantazis Mouroulis \\ Editors
}

24 August - 4 September 2020

Online Only, United States

Sponsored and Published by

SPIE

Volume 11504 
The papers in this volume were part of the technical conference cited on the cover and title page. Papers were selected and subject to review by the editors and conference program committee. Some conference presentations may not be available for publication. Additional papers and presentation recordings may be available online in the SPIE Digital Library at SPIEDigitalLibrary.org.

The papers reflect the work and thoughts of the authors and are published herein as submitted. The publisher is not responsible for the validity of the information or for any outcomes resulting from reliance thereon.

Please use the following format to cite material from these proceedings:

Author(s), "Title of Paper," in Imaging Spectrometry XXIV: Applications, Sensors, and Processing, edited by Emmett J. Ientilucci, Pantazis Mouroulis, Proceedings of SPIE Vol. 11504 (SPIE, Bellingham, WA, 2020) Seven-digit Article CID Number.

ISSN: 0277-786X

ISSN: 1996-756X (electronic)

ISBN: 9781510638143

ISBN: 9781510638150 (electronic)

Published by

SPIE

P.O. Box 10, Bellingham, Washington 98227-0010 USA

Telephone +1 3606763290 (Pacific Time) · Fax +1 3606471445

SPIE.org

Copyright (c) 2020, Society of Photo-Optical Instrumentation Engineers.

Copying of material in this book for internal or personal use, or for the internal or personal use of specific clients, beyond the fair use provisions granted by the U.S. Copyright Law is authorized by SPIE subject to payment of copying fees. The Transactional Reporting Service base fee for this volume is $\$ 21.00$ per article (or portion thereof), which should be paid directly to the Copyright Clearance Center (CCC), 222 Rosewood Drive, Danvers, MA 01923. Payment may also be made electronically through CCC Online at copyright.com. Other copying for republication, resale, advertising or promotion, or any form of systematic or multiple reproduction of any material in this book is prohibited except with permission in writing from the publisher. The CCC fee code is $0277-$ $786 \mathrm{X} / 20 / \$ 21.00$.

Printed in the United States of America by Curran Associates, Inc., under license from SPIE.

Publication of record for individual papers is online in the SPIE Digital Library.

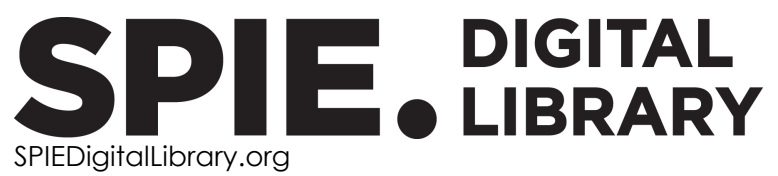

Paper Numbering: Proceedings of SPIE follow an e-First publication model. A unique citation identifier (CID) number is assigned to each article at the time of publication. Utilization of CIDs allows articles to be fully citable as soon as they are published online, and connects the same identifier to all online and print versions of the publication. SPIE uses a seven-digit CID article numbering system structured as follows:

- The first five digits correspond to the SPIE volume number.

- The last two digits indicate publication order within the volume using a Base 36 numbering system employing both numerals and letters. These two-number sets start with $00,01,02,03,04$, 05, 06, 07, 08, 09, OA, OB ... 0Z, followed by 10-1Z, 20-2Z, etc. The CID Number appears on each page of the manuscript. 


\title{
Contents
}

\author{
MISSION SENSOR DESIGN
}

1150402 Optical design of the Earth Surface Mineral Dust Source Investigation (EMIT) imaging spectrometer [11504-1]

1150403 Ultra-Compact Imaging Spectrometer Moon (UCIS-Moon) for lunar surface missions: optical, optomechanical, and thermal design [11504-2]

\section{SENSOR DEVELOPMENT}

$1150406 \quad$ Compact imaging spectrometer for planetary missions [11504-5]

1150407 Snow and water imaging spectrometer: final instrument characterization [1 1504-6]

1150408 Design of a highly sensitive position-sensitive detector based on redshifts in photoluminescence spectra [11504-7]

HYPERSPECTRAL DATA PROCESSING, EXPLOITATION, AND ALGORITHMS

11504 OA Matrix completion for compressive sensing using consensus equilibrium [1 1504-9]

$11504 \mathrm{OB} \quad$ Toward comprehensive uncertainty predictions for remote imaging spectroscopy (Invited Paper) [11504-10]

11504 OD Evaluation of an automated channel-selection method for application on the retrieval of different gas profiles from ultra-spectral thermal infrared data [11504-12]

\section{ALGORITHMS, APPLICATIONS, AND RADIATIVE TRANSFER}

$11504 \mathrm{OF}$ Consensus anomaly detection using clustering methods in hyperspectral imagery [11504-14]

11504 OG Detection and identification of plastics using SWIR hyperspectral imaging [1 1504-15] 


\section{POSTER SESSION}

$115040 \mathrm{~J}$ Sentinel-2 red-edge spectral indexes best suited to discriminate burned from unburned areas in Mediterranean forest ecosystems [11504-18] 